\title{
Perancangan Souvenir Beridentitas Tradisi Telingaan Aruu Khas Suku Dayak
}

\author{
Wyna Herdiana $^{1}$,Theresia Firstianti Santoso ${ }^{2}$ \\ ${ }^{1,2}$ Program Studi Desain Produk, Fakultas Industri Kreatif, Universitas Surabaya, \\ Raya Kalirungkut Surabaya 60293, Indonesia \\ wynaherdiana@yahoo.co.id
}

Suku Dayak merupakan salah satu suku yang terdapat di Kalimantan yang memiliki kebudayaan "Telingaan Aruu" yang sangat khas. Tradisi tersebut merupakan tradisi yang diteruskan secara turun temurun kepada para wanita suku Dayak. Namun, tradisi ini sudah mulai ditinggalkan karena anggapan bahwa tradisi tersebut sudah ketinggalan jaman. Oleh karena itu perlu ada pengenalan mengenai kebudayaan tersebut kepada masyarakat umum, agar generasi muda tetap mengetahui adanya tradisi tersebut di Indonesia. Hal inilah yang membuka peluang untuk dibuatnya perhiasan sebagai salah satu bentuk souvenir khas suku Dayak. Tujuan yang ingin dicapai pada penelitian ini adalah 1). Pembuatan alternatif desain perhiasan yang mengangkat kebudayaan "Telingaan Aruu" yang akan dijadikan sebagai souvenir khas Suku Dayak, tradisi tersebut merupakan tradisi khas suku Dayak yang sudah mulai punah; 2) Perwujudan prototype dari alternatif desain. Konsep desain yang digunakan adalah Massive Jewelry with Telingaan Aruu Tradition Typical of Dayak Tribe yaitu kata kunci Massive diambil karena perhiasan dibuat dalam ukuran cukup besar yang eyecatching, perhiasan besar mengandung makna bahwa kesanggupan dalam menahan derita suku Dayak cukup besar. Metode yang digunakan adalah dengan analisis aspek teknis dan aspek estetis dengan stilasi dan deformasi bentuk. Hasil yang diperoleh adalah pembuatan souvenir berupa perhiasan dengan bahan dasar perak dan terdiri dari beberapa jenis perhiasan, yaitu gelang, kalung, anting-anting, dan cincin.

Kata kunci: Suku Dayak, Perhiasan, Perak

\section{Souvenir Design with the Identity of Telingaan Aruu from Dayak Tribe}

Dayak tribe is one of many tribes in Kalimantan with a distinctive tradition of "Telingaan Aruu". This tradition is passed through many generations of Dayak women. However, this tradition is now facing the threat of extinction. Therefore, there was a strong need to brought back the tradition to the wider public as a keepsake for many generations about to come. By this ground, there was an opportunity to design a Dayak tribe inspired souvenir with a form of jewelry. Accordingly, this research has two aims: 1) to create some design alternatives with "Telingaan Aru" as the main inspiration for Dayak tribe souvenir, in order to save the tradition from extinction; 2) to create the prototype from the design alternatives. The design concept is "Massive Jewelry with Telingaan Aruu Tradition Typical of Dayak Tribe". "Massive" itself was chosen to be the keyword as the jewelry will be designed with eyecatching massive size, in which this massive size also has the meaning of willingness to withstand all the suffer in Dayak tribe life. The research will utilize the technical and esthetical aspects analysis method with stylation and deformation. Furthermore, this research resulted in a Dayak tribe souvenir in a form of jewelry such as bracelet, necklace, earrings, and ring; with silver as the main material.

Keyword: Dayak tribe, Jewelry, Silver

Proses Review : 1 - 31 Maret 2018, Dinyatakan Lolos: 10 April 2018 


\section{PENDAHULUAN}

Indonesia termasuk dalam negara yang memiliki banyak kekayaan sumber daya alam dan keanekaragaman budaya yang tersebar di berbagai tempat di Indonesia. Dalam perkembangannya, masyarakat Indonesia semakin memiliki pengetahuan yang luas dan sadar akan adanya teknologi. Hal ini membuat kualitas sumber daya manusia semakin meningkat dengan adanya kemampuan untuk mengolah sumber daya alam dengan tetap mempertahankan ciri khas kebudayaan setempat.

Salah satu pulau di Indonesia yang memiliki keragaman budaya yaitu Pulau Kalimantan. Kalimantan memiliki banyak keunikan dan daya tarik tersendiri, khususnya warisan kebudayaannya. Wilayah ini terkenal dengan hutan tropis serta memiliki sumber daya alam terbanyak di Indonesia. Pada mulanya, pulau ini dihuni oleh orang-orang Dayak sebagai penduduk asli Kalimantan. Biasanya mereka tinggal di dalam hutan dan hidup secara nomaden. Ciri khas dari orang suku Dayak yaitu memanjangkan cuping telinganya yang disebut dengan istilah "Telingaan Aruu". Tradisi ini diwariskan secara turun temurun dari generasi ke generasi. Memanjangkan cuping telinga biasanya untuk menunjukkan status sosial dan kecantikan di beberapa suku Dayak tertentu. Selain itu, hal ini dimaksudkan untuk melatih kesabaran dan kesanggupan menahan derita.

Namun pada perkembangannya saat ini, masyarakat suku Dayak yang memanjangkan cuping telinganya sangat jarang ditemui. Hanya sebagian kecil warga saja yang masih menerapkannya. Rata-rata mereka adalah generasi tua yang telah berusia diatas 60 tahun, bahkan sebagian penduduk yang dulunya bertelinga panjang secara sengaja memotong ujung daun telinganya. Hal ini disebabkan karena anggapan bahwa tradisi itu sudah ketinggalan jaman. Selain itu, mereka juga khawatir anak-anaknya merasa malu jika mereka tetap mempertahankan telinga panjang tersebut.

Menurut penduduk desa pemanjangan daun telinga di kalangan masyarakat Kenyah secara tradisional berfungsi sebagai penanda identitas kemanusiaan mereka. Orangorang yang tidak bertelinga panjang dianggap serupa dengan kera. Disamping itu, ada juga yang mengatakan bahwa kebiasaan memanjangkan telinga muncul dari kepercayaan masyarakat Kenyah pada Bungan Malam, sesosok roh cantik bertelinga panjang (Dr. Yekti Maunati, 2004).

Tradisi telinga panjang dilakukan sebagai pembeda dan menunjukkan status sosial masyarakat suku Dayak. Dalam satu rumah lamin terdapat derajat kepangkatan, pembagian kewenangan politis, dan pemegang warisan adat. Orang-orang yang dianggap penting diberi tanda khusus, salah satunya yaitu dengan tradisi telinga panjang. Telinga panjang mewakili orang yang kaya dan kuat secara poli-

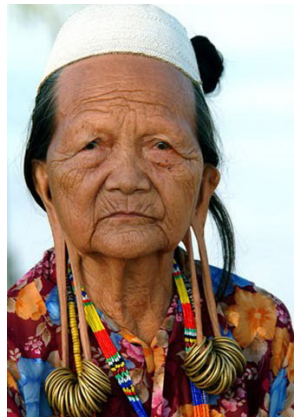

Gambar 1. Tradisi "Telingaan Aruu”. (Sumber: https://smedia-cache-ak0.pinimg.com/originals/f4/4b/a9/

f44ba948387eb2750812ed588a11762e.jpg, diunduh tanggal 28

Februari 2017)

tik dan adat. Kehormatan akan hak telinga panjang bisa disematkan baik pada pria maupun perempuan, karena sifat kekerabatan dayak yang kognatik.

Memanjangkan cuping telinga juga untuk menunjukkan kecantikan, dimana suku Dayak memandang nilai kecantikan pada saat lubang telinga telah panjang dengan banyak anting-anting maka kecantikan seakan lebih terpancar dari wajah mereka (Ati Bachtiar, 2017) Selain itu, ada yang mengatakan bahwa memanjangkan telinga untuk menguji kesabaran dan kesanggupan dalam menanggung beban hidup.

Rakyat sebagai penyangga kekuatan dasar industri kreatif harus dimotivasi untuk produktif dan mandiri dalam ekonomi. Berkepribadian dalam berkebudayaan artinya rakyat Indonesia harus memiliki akar kultural yang kuat sebagai landasan pembentukan karakter kepribadian agar tidak tercabut dari akar budayanya sendiri (Martono, Iswahyudi and Handoko, 2017).

Semakin punahnya tradisi memanjangkan cuping telinga ini dapat memberikan dampak negatif bagi generasi muda dalam suku Dayak. Perlahan-lahan, mereka akan melupakan adanya tradisi tersebut dan juga merasa malu jika harus meneruskan tradisi tersebut. Tradisi semacam ini patut untuk dilestarikan agar generasi penerus suku Dayak tetap dapat memahami maksud dari kebudayaannya sendiri dan menjadikan hal ini sebagai sebuah ciri khas yang patut dikenal oleh dunia luar. Pemikiran yang harus ditanamkan yaitu bahwa tidak ada yang perlu untuk dijadikan hal memalukan, melainkan sesuatu yang membanggakan.

Terkadang ciri khas suku Dayak dan maknanya kurang dikenal oleh orang dari luar. Oleh karena itu, ciri khas ini perlu diperkenalkan pada dunia luar. Salah satu cara untuk memperkenalkan ciri khas suku Dayak yaitu dengan membuat Souvenir khas daerah tersebut. Souvenir khas suku Dayak yang sudah ada, diantaranya yaitu miniatur suku dayak, Souvenir aneka manik-manik (gelang, tas, taplak, dan kotak tissue), sarung Samarinda. Perhiasan juga dapat dijadikan salah satu Souvenir khas dimana perhiasan 
dapat menambah kecantikan seorang wanita suku Dayak. Hal ini dapat dilihat pada para wanita yang menggunakan perhiasan pada telinganya dalam tradisi "Telingaan Aruu". Semakin banyak anting-anting yang digunakan maka akan semakin cantik pula wanita itu karena telinganya pun ikut memanjang.

Disamping itu, perhiasan adalah hal yang tidak dapat dipisahkan dari wanita. Perhiasan dapat menunjang penampilan seseorang yang memakainya. Selain dapat menunjang penampilan, perhiasan juga dapat meningkatkan rasa percaya diri penggunanya. Dengan penggunaan perhiasan, kekurangan si pengguna akan dapat tertutupi. Terbukti, walaupun mengenakan pakaian yang sederhana namun pengguna masih dapat terlihat anggun dengan menggunakan perhiasan yang cantik.

\section{METODE PENCIPTAAN}

Perhiasan dibuat dengan mempertimbangkan metode penelitian kualitatif dan mempertimbangkan aspek yang digunakan untuk merancang suatu produk. Aspek tersebut dibagi menjadi dua yaitu aspek teknis dan aspek rupa. Untuk perwujudan bentuk menggunakn metode stilasi dan deformasi.

\section{Aspek Teknis \\ Pengguna}

Aspek pengguna dalam perancangan perhiasan adalah mahasiswa dan pekerja kantoran. Beberapa hal yang perlu diperhatikan dalam aspek pengguna : Jenis Kelamin Perempuan, Usia Dewasa Awal, 20-45 tahun, Perhiasan ditujukan untuk para wanita dengan kategori menengah-keatas dengan melihat kebutuhan akan pelengkap suatu penampilan

\section{Fungsi}

Jewerly memiliki arti kegembiraan. Berdasarkan sejarah yang ada, alasan utama menggunakan jewerly untuk menambah kebahagiaan dan kegembiraan dalam hidup. Jewerly memiliki banyak fungsi: Ekspresi cinta, kasih sayang dan komitmen, Simbol keberuntungan, Simbol religi, Melambangkan kecantikan, Hadiah yang sangat ideal untuk saat-saat istimewa (Newman, 2007)

Perhiasan bukanlah sekedar sebuah barang yang bisa membuat orang terlihat cantik dan menarik atau untuk bergaya, namun lebih dari itu perhiasan dimaknai sebagai status seseorang di dalam masyarakat. Dalam hal ini jika seseorang menggunakan perhiasan, apapun bentuknya maka orang tersebut akan dipahami sebagai orang berada pada status kelas tertentu. Memahami bahwa perhiasan dapat menunjukkan status sosial seseorang di dalam masyarakat, maka tidak mengherankan jika menggunakan perhiasan kini menjadi gaya hidup masyarakat (Arsa, I Ketut Sida and Laba, I Nyoman, 2016, p. 229).

\section{Antropometri}

Antoropometri merupakan aspek terpenting dalam menunjang suatu produk yang ergonomis. Data antropometri yang dijadikan dasar acuan dalam perancangan produk ini adalah data antropometri wanita di Indonesia mulai dari usia 20 tahun sampai dengan 45 tahun, dengan dimensi dan kegunaannya sebagai berikut:

Tabel 1. Data antropometri orang dewasa di Indonesia usia 2045 tahun (Sumber: http://antropometriindonesia.org/)

\begin{tabular}{llll}
\hline No & $\begin{array}{l}\text { Jenis } \\
\text { Perhiasan }\end{array}$ & Ukuran & Keterangan \\
\hline 1 & Kalung & $46 \mathrm{~cm}$ & $\begin{array}{l}\text { Mengambil ukuran } \\
\text { kecil }\end{array}$ \\
\hline 2 & Gelang & $17,5 \mathrm{~cm}$ & $\begin{array}{l}\text { Mengambil ukuran } \\
\text { kecil }\end{array}$ \\
\hline 3 & Anting- & standar & $\begin{array}{l}\text { Mengambil ukuran } \\
\text { orang dewasa }\end{array}$ \\
\hline 4 & anting & & Mengambil ukuran \\
& Cincin & $5,9-6,1 \mathrm{~cm}$ & sedang \\
\hline
\end{tabular}

\section{Material}

Perhiasan yang dirancang menggunakan material yaitu perak dan manik-manik. Perak memiliki karakteristik yaitu tahan terhadap air dan keringat, bentuk yang dihasilkan, tahan lama, dan juga tingkat kerapian. Manik-manik memiliki karakteristik yaitu ringan, kemudahan proses produksi dan keterjangkauan harga. Setelah dilakukan pembobotan material, maka material yang digunakan untuk badan perhiasan yaitu suasa. Pernik perhiasan menggunakan manik-manik dan material perak untuk digunakan sebagai finishing perhiasan.

Penggunaan perak sebagai material utama karena perak melambangkan kekayaan dan kemakmuran (Newman, 2007).

\section{Sistem}

Pada produk yang dirancang, sistem yang digunakan adalah sistem kaitan pengunci perhiasan dan bentuk perhiasan yang dibuat agar tidak mudah lepas. Berikut ini merupakan sistem pengunci perhiasan yang akan digunakan:

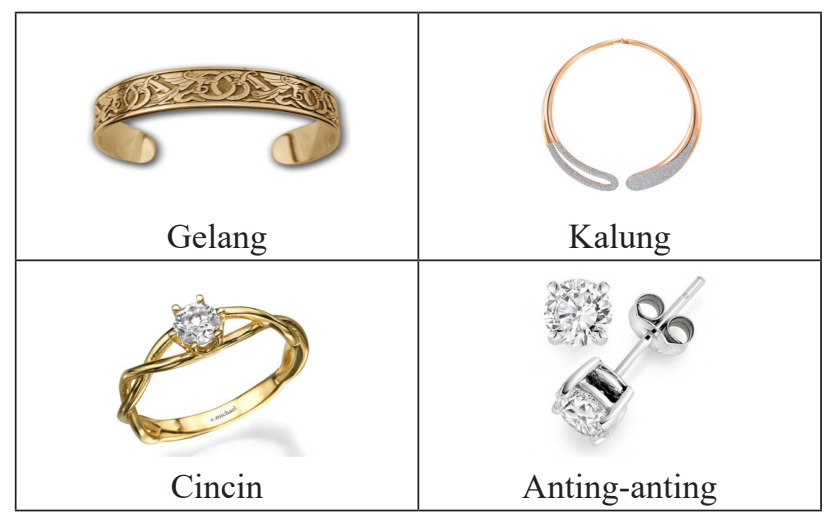

Gambar 2. Sistem pengunci perhiasan yang akan digunakan. 


\section{Keamanan}

Material yang digunakan adalah material perak, dimana material ini aman untuk digunakan sehari-hari dan tidak menimbulkan alergi pada kulit. Agar perhiasan yang telah dibuat nanti lebih tahan lama dan aman, perhiasan dapat dibersihkan dalam jangka waktu tertentu dan dapat dilapis perak lagi.

\section{Sosial Budaya}

Tradisi "Telingaan Aruu" khas suku Dayak mempunyai makna menunjukkan status sosial, bangsawan atau budak. Selain itu juga untuk menunjukkan tingkat kecantikkan seseorang dan usia seseorang.

\section{Aspek Rupa}

Aspek rupa memiliki pengaruh yang sangat besar pada penampilan sebuah produk. Terdapat beberapa unsur yang perlu diperhatikan, diantaranya adalah warna, bentuk, dan tekstur. Berikut ini adalah pembahasan mengenai unsur-unsur rupa yang diterapkan pada produk:

\section{Warna}

Warna yang digunakan adalah dominan warna silver agar terlihat glamour dan mahal. Untuk warna pemanis diberi manik-manik dengan warna merah yang berarti semangat hidup dan keberanian. Warna yang terkait dengan gaya desain massive yaitu warna dominan silver dimana akan terkesan lebih besar dan eye catching.

\section{Bentuk}

Menurut Bambang Irawan dan Priscilla Tamara (2013), inspirasi bentuk pada dasarnya dapat diambil dari alam ataupun dari berbagai bentuk dasar yang diciptakan oleh manusia. Bentuk yang diterapkan pada perhiasan merupakan bentuk organis yang melambangkan kelemahlembutan. Bentuk juga diadaptasi dari bentuk telinga dari tradisi "Telingaan Aruu" yang menjadi ciri khas suku Dayak.

\section{Tekstur}

Tekstur yang digunakan pada produk yang dirancang adalah tekstur nyata yang didapatkan dari finishing pada material perhiasan. Tekstur dapat dirasakan dengan meraba dan melihat.

\section{Estetika}

Estetika yang diterapkan dalam rancangan produk yaitu mengambil konsep massive yang menjadi trend spring-summer di tahun 2017. Perhiasan yang nantinya dibuat memiliki ukuran yang cukup besar jika dikenakan sesuai dengan konsep desain yang digunakan.

\section{Konsep Desain}

Massive Jewelry with Telingaan Aruu Tradition Typical of Dayak Tribe

Perhiasan dibuat dalam ukuran cukup besar yang eyecatching. Perhiasan tersebut mengambil bentuk dari tradisi "Telingaan Aruu" untuk diterapkan dalam prototype.
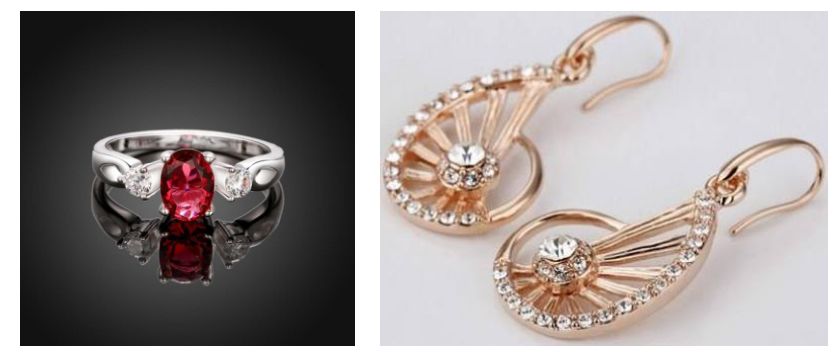

Gambar 3 (Kiri). Penerapan warna silver dan merah pada perhiasan. (Sumber : https://www.nayyo.com/3941/c10122-cincinkristal-cantik.jpg, diunduh pada 3 April 2017)

Gambar 4 (Kanan). Contoh penerapan bentuk organis pada perhiasan. (Sumber : https://encrypted-tbn1.gstatic.com/images?q=tbn:ANd9GcRqfrK5G1jJXZyx6Ch8hi0AxhHP8n5O9FOjIGT8i_cJFL6K3q_kjR5asa9_Kg, diunduh pada 9 Maret 2017)

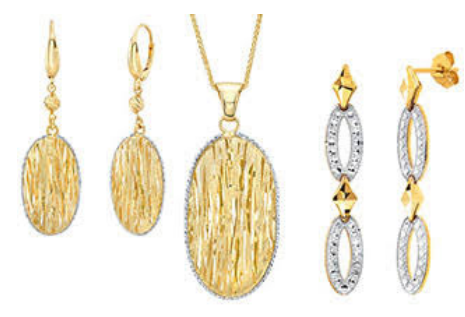

Gambar 5. Contoh tekstur nyata pada perhiasan. (Sumber : https://encrypted-tbn0.gstatic.com/images?q=tbn:ANd9GcTLnlJ2xQLnMavhABXviUIKlcF_0j8z8WZtW_zgr1VAH-sb4zBc7g, diunduh pada 9 Maret 2017)

Tradisi tersebut merupakan tradisi khas suku Dayak yang sudah mulai punah.

Massive: ukuran perhiasan yang dibuat cukup besar sehingga eyecatching. Selain itu, perhiasan besar mengandung makna bahwa kesanggupan dalam menahan derita suku Dayak cukup besar.

Jewelry: bentuk produk yang akan dijadikan Souvenir khas suku Dayak, meliputi gelang, kalung, cincin, dan anting-anting.

Telingaan Aruu Tradition: tradisi yang diangkat menjadi bentuk perhiasan.

Typical of Dayak Tribe: kekhasan suku Dayak yang sudah dikenal dimana-mana, namun sudah mulai punah karena terseret arus modern.

\section{Citra Desain}

Citra desain pada perancangan produk ini menggunakan dua sumbu yaitu Simple-Complex dan Traditional-Modern, yang mengacu pada gaya desain perancangan produk. Sumbu Simple-Complex merupakan kategori dimana ditentukan oleh bentuk dan Sedangkan sumbu Traditional-Modern merupakan kategori perhiasan yang menggambarkan model bentuk visual yang tertangkap mata pertama kali.

Berdasarkan image chart diatas, kesan yang ingin ditampilkan adalah Simple-Modern. Dengan kesan tersebut, bentuk perhiasan yang dibuat yaitu sederhana dan 


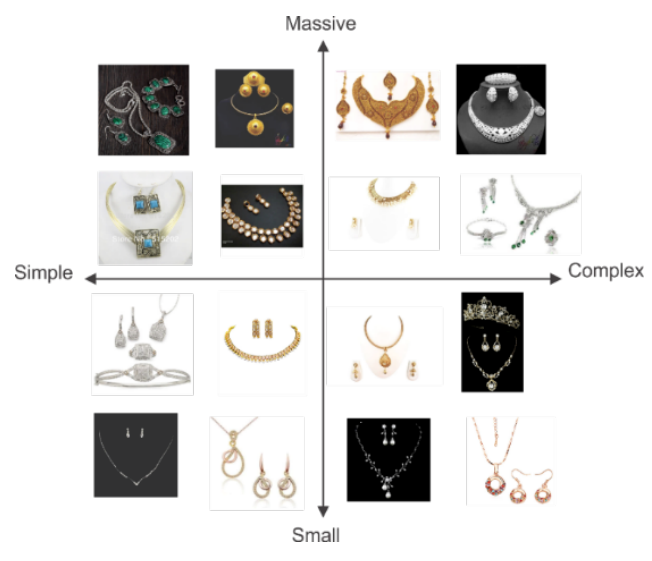

Gambar 6. Citra Desain.

Sumber: Dokumentasi Penulis

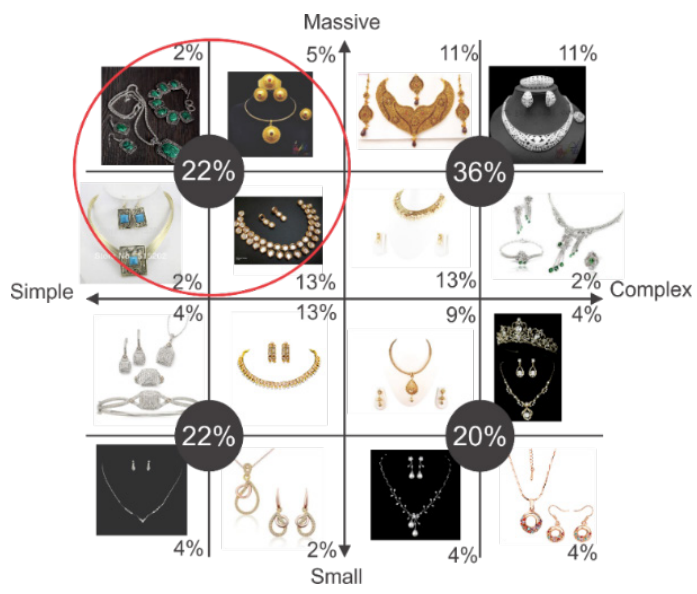

Gambar 7. Image Chart.

Sumber: Dokumentasi Penulis

menampilkan kesan modern. Selain itu agar perhiasan juga dapat digunakan untuk acara-acara tertentu.

Berdasarkan image board diatas, produk yang akan dirancang memiliki bentuk yang sederhana dan modern. Warna-warna yang digunakan pun tidak terlalu mencolok dan tetap menunjukkan kesan elegan.

Berdasarkan mood board diatas, produk yang akan dirancang merupakan produk yang memiliki bentuk sederhana. Pengguna yang dituju yaitu wanita yang berprofesi sebagai pekerja kantoran dan mahasiswa. Ukuran dari produk yang akan dibuat cukup besar.

\section{Landasan Desain}

Landasan desain dari perhiasan merupakan bentuk inovasi untuk melestarikan tradisi "Telingaan Aruu" khas suku Dayak yang sudah mulai punah. Perhiasan ini dibuat guna mengenalkan makna tradisi "Telinggaan Aruu" kepada orang luar. Perhiasan dibuat dengan ukuran yang eyecatching.

\section{Spesifikasi Desain}

Dimensi produk

: Gelang (17,5 cm), Kalung (46

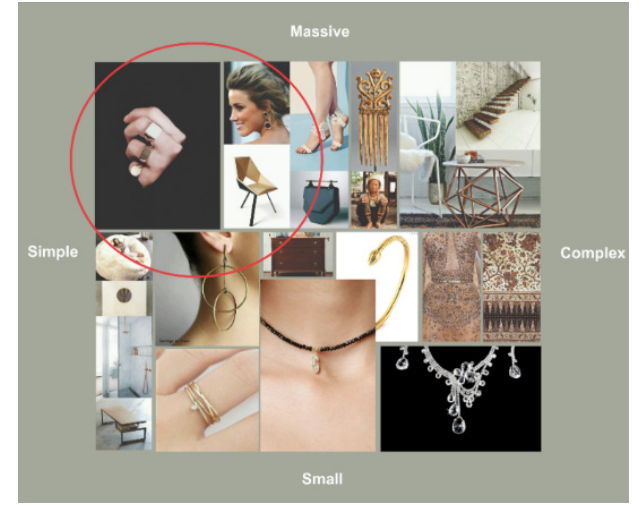

Gambar 8. Image Board.

Sumber: Dokumentasi Penulis

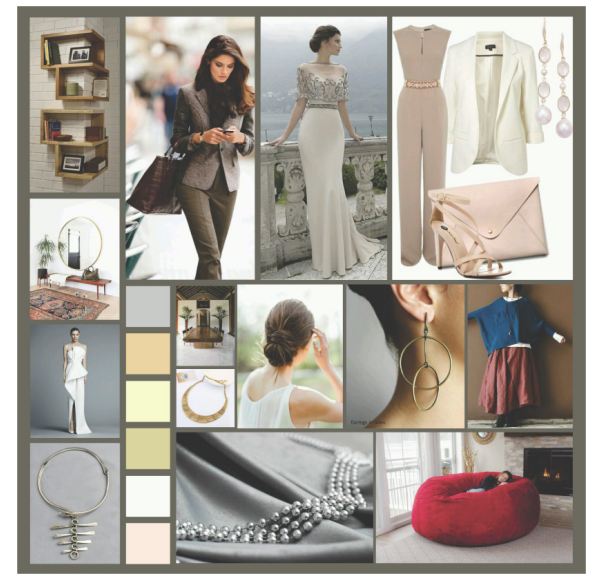

Gambar 9. Mood board.

Sumber: Dokumentasi Penulis

$\mathrm{cm})$, Cincin (5,9-6,1 cm), Anting-anting (standar)

Jenis material

: Perak dan manik kristal kaca

\section{PROSES PERWUJUDAN}

\section{Alternatif Desain}

Tabel 4. 3 Alternatif Studi Model

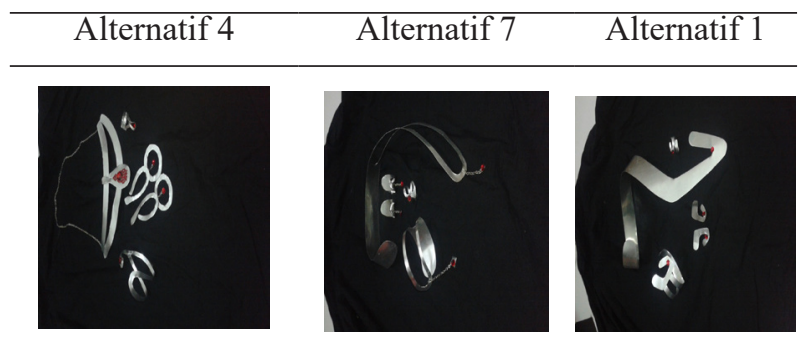

Sumber: Dokumentasi Penulis

\section{Final Desain}

Setelah alternatif 1 terpilih untuk dijadikan prototype maka dibuatlah final desain seperti pada gambar dibawah ini: 

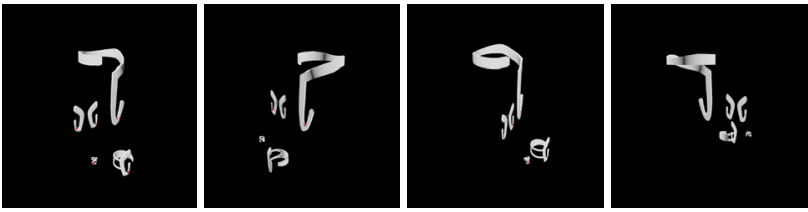

Gambar 10. Final desain dari berbagai tampak Sumber: Dokumentasi Penulis
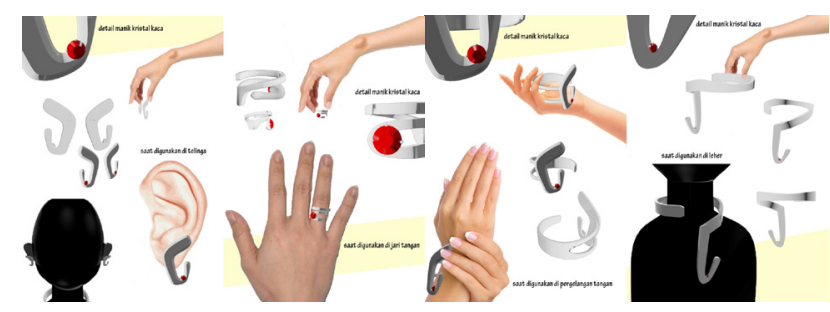

Gambar 11. Gambar operasional Sumber: Dokumentasi Penulis

\section{WUJUD KARYA}

Prototype

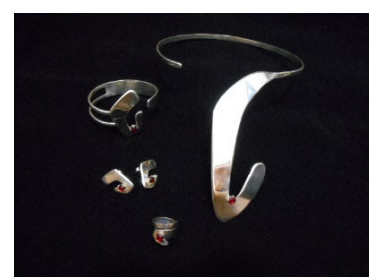

Gambar 12. Prototype

Sumber: Dokumentasi Penulis

Operasional produk

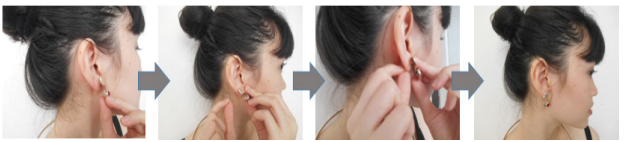

Gambar 13. Cara menggunakan anting Sumber: Dokumentasi Penulis

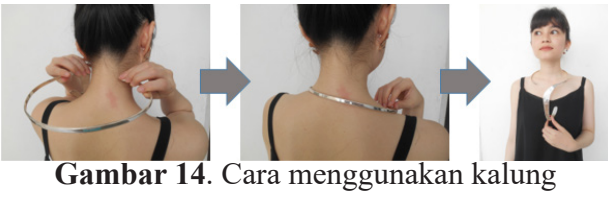

Sumber: Dokumentasi Penulis

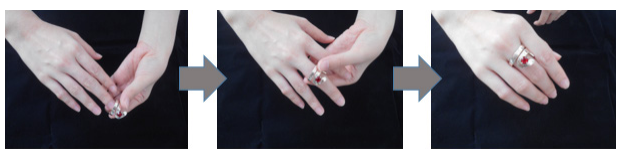

Gambar 15. Cara menggunakan cincin Sumber: Dokumentasi Penulis
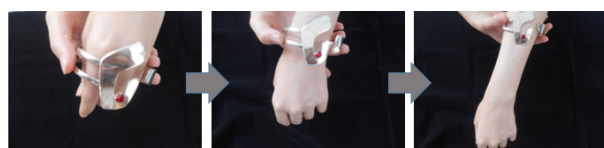

Gambar 16. Cara menggunakan gelang Sumber: Dokumentasi Penulis
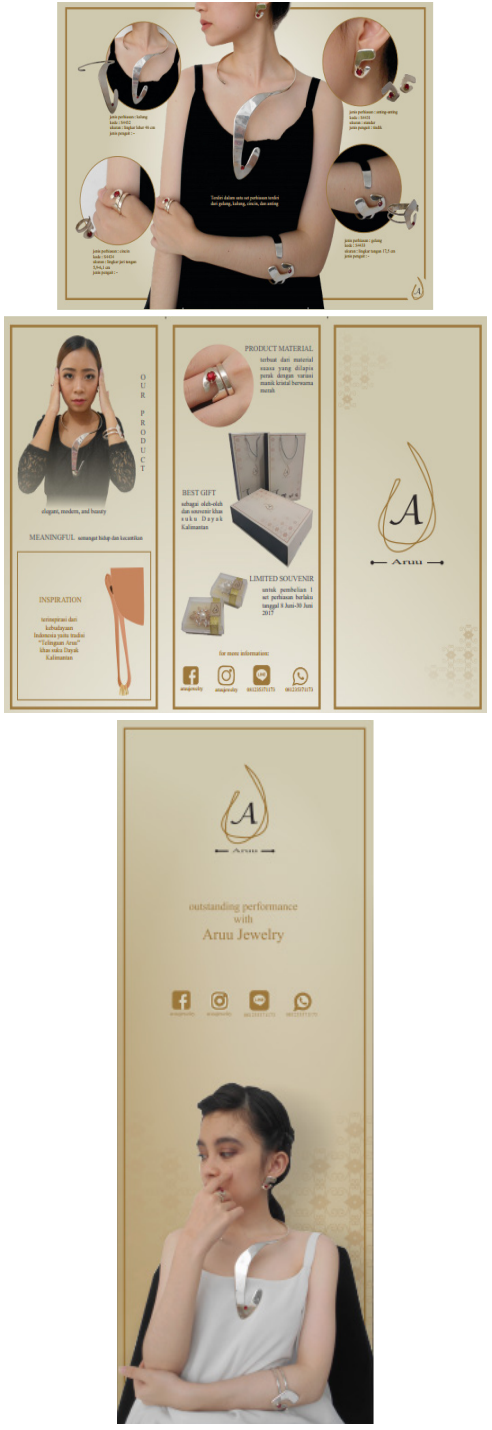

Gambar 17. Final Desain Sumber: Dokumentasi Penulis

\section{SIMPULAN}

Tradisi "Telingaan Aruu” dapat dikenal dengan adanya perhiasan modern yang dapat digunakan oleh masyarakat luar selain orang Dayak. Banyak inspirasi desain dari kebudayaan telinga panjang suku Dayak yang dapat dijadikan alternatif desain perhiasan Aruu, khususnya bentuk anting-anting telinga panjang sebagai salah satu icon yang bermacam-macam bentuknya. Dalam membuat suatu perhiasan, kita harus memahami konsumen yang menjadi target. Perhiasan harus mampu disesuaikan dengan kebutuhan konsumen akan suatu kegiatan, tempat yang akan dituju, dan ukuran tubuh konsumen yang ditargetkan. Dari segi desain, Aruu dapat mengambil inspirasi dari potensi-potensi yang ada pada suku Dayak, selain yang telah dibahas pada penulisan ini. 


\section{DAFTAR RUJUKAN}

Adams, Maia. (2012). Fashion Jewellery: Catwalk and Couture. Laurence King Publishing. London

Arsa, I Ketut Sida and Laba, I Nyoman. (2016). Diversifikasi Bahan dan Teknik Penciptaan Perhiasan Sebagai Pemenuhan Kebutuhan Gaya Hidup Masyarakat di Era Postmodern, MUDRA, 31 (2), Retrieved from http://jurnal.isi-dps.ac.id/index.php/mudra/article/view/33/8

Bachtiar, Ati. (2016). Telinga Panjang Mengungkap yang Tersembunyi. Jakarta: RBS

Irawan, Bambang dan Tamara. (2013). Dasar-dasar Desain. Jakarta: Griya Kreasi, hal 25-28

Maunati, Dr. Yekti. (2004). Identitas Dayak. Yogyakarta: PT. LKIS Pelangi Aksara

Martono, Iswahyudi, and Handoko, Aran. (2017). Topeng Etnik Nusantara Dalam Perkembangan Budaya Global, MUDRA, 32 (1), Retrieved from http://jurnal.isi-dps. ac.id/index.php/mudra/article/view/91/43

Newman, Renee. (2007). How to Select, Wear \& Care for Jewerly. International Jewerly Publications. Los Angeles 